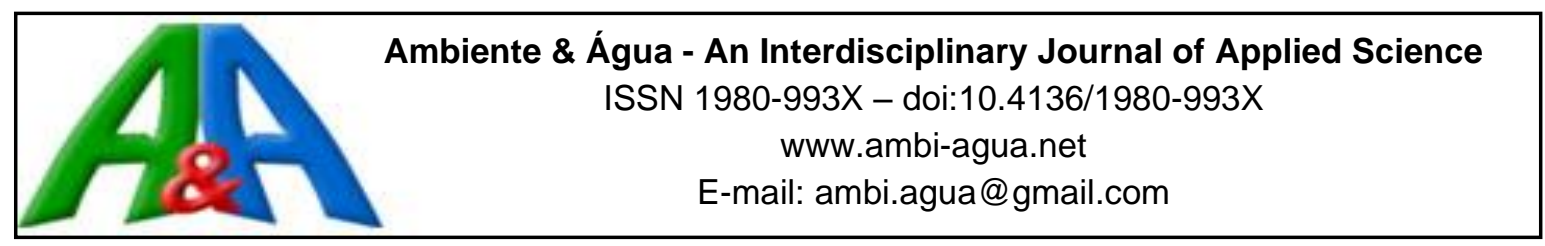

\title{
Determination of the junction angle in fluvial channels from georeferenced aerial images from Google Earth Pro and UAV
}

\author{
ARTICLES doi:10.4136/ambi-agua.2345
}

Received: 05 Nov. 2018; Accepted: 25 Jun. 2019

\begin{abstract}
Marco Alésio Figueiredo Pereira ${ }^{*}$ (D); Bruno Lippo Barbieiro ${ }^{1(D ;}$ Marciano Carneiro ${ }^{2}$; Masato Kobiyama ${ }^{3}$ (D)
${ }^{1}$ Programa de Pós-graduação em Qualidade Ambiental (PPGQA), Universidade FEEVALE (FEEVALE), ERS- 239, n 2755, CEP 93525-075, Novo Hamburgo, RS, Brazil. E-mail: brunolippo7@ gmail.com CEP 93022-750, São Leopoldo, RS, Brazil. E-mail: marciano.carneiro@ hotmail.com Sul (UFRGS), Avenida Bento Gonçalves, n 9500, CEP 91501-970, Porto Alegre, RS, Brazil.
E-mail: masato.kobiyama@ufrgs.br
*Corresponding author. E-mail: marco@feevale.br ${ }^{2}$ Departamento de Engenharia, Universidade do Vale do Rio dos Sinos (UNISINOS), Avenida Unisinos, $\mathrm{n}^{\circ}$ 950,

${ }^{3}$ Instituto de Pesquisas Hidráulicas, Departamento de Obras Hidráulicas, Universidade Federal do Rio Grande do
\end{abstract}

\begin{abstract}
The junction angles in fluvial channels are determined from complex erosion and deposition processes, resulting from river-flow dynamics, bed and margin morphology, and so on. Knowledge regarding these angles is important in order to better understand the existing conditions in a basin. In this sense, the objective of the present study was to determine the junction angles on fluvial channels, called $\alpha, \beta$ and $\gamma$, applying the law of cosines. Georeferenced Google Earth Pro images and UAV images were used. Then, the values calculated from the georeferenced aerial images were compared with the values calculated from the minimum energy principle. To visualize and understand the obtained angles, the Junction Angles Diagram was used. The obtained result shows that the methodology using georeferenced aerial images have good performance for determining junction angles on fluvial channels.
\end{abstract}

Keywords: georeferencing, junction angle, law of cosines.

\section{Determinação do ângulo de junção em canais fluviais a partir de imagens aéreas georreferenciadas obtidas do Google Earth Pro e com VANT}

\section{RESUMO}

Os ângulos de junção em canais fluviais são determinados a partir de complexos processos de erosão e deposição, resultantes da dinâmica do fluxo da vazão, da morfologia do leito e das margens, das feições hidrogeomorfológicas da bacia, de sua ordem e do uso e da ocupação do solo. Conhecer os valores desses ângulos é importante para melhor entender as condições atuantes na bacia em estudo. Nesse sentido, o presente trabalho teve por objetivo determinar os ângulos de junção em canais fluviais, denominados $\alpha, \beta$ e $\gamma$, aplicando a lei dos cossenos. Foram utilizadas imagens aéreas do Google Earth Pro e coletadas VANT. Então, determinou-se os valores dos ângulos obtidos a partir dessas imagens, comparando-as aos valores calculados a partir do princípio da energia mínima. Para visualização e entendimento dos ângulos obtidos, (c) This is an Open Access article distributed under the terms of the Creative Commons Attribution License, which permits unrestricted use, distribution, and reproduction in any medium, provided the original work is properly cited. 
foi utilizado o diagrama de ângulos de junção, sendo possível afirmar que a metodologia utilizando a lei dos cossenos, apresentou bons resultados para a determinação de ângulos de junção em canais fluviais.

Palavras-chave: ângulo de junção, imagens aéreas, lei dos cossenos.

\section{INTRODUCTION}

The understanding of hydrodynamics and morphodynamics at the confluence of fluvial channels is of a great interest for researchers in hydrology, fluvial geomorphology and sedimentology. Junctions' angles are an important fluvial feature, as well as a critical component of the drainage network, which, in turn, makes up the river basin. Small (1978) stated that drainage systems had been always highlighted both for men and for the mechanisms of landscape transformation, because they are linked to the dissection processes and landforms (re)modeling, being correlated with the slope and discharge at their junctions. Small (1978) and Beven et al. (1988) reported that the present landforms result from the sum of the processes related to the rivers and the hillslopes, variation of magnitude and frequency of such processes along geological time.

According to Santos and Stevaux (2017), scientific interest in geomorphic processes occurring at channel confluences has increased in the last decades, due to the growing awareness that the river processes and the confluence morphology reflect the characteristics of the upstream basin. Such geomorphic processes also play an important role in the regulation of water and sediment delivers in the downstream drainage network, because the interaction between the hydrological, geological and geomorphic mechanisms seeks to promote equilibrium between the natural processes that occur in the basin (Leopold and Maddock Jr., 1953). Although many studies on junction angles have been done up until now (Best and Rhoads, 2008; Santos and Stevaux, 2017), knowledge about its formation and determination still maintains strong interest (Hooshyar et al., 2017; Alomari et al., 2018; Yukawa et al., 2019). However, the majority of the studies in this topic is directed to the understanding of the flow regime, of the interactions that occur inside the channel, and of the sediment mobility of the channels (Park and Latrubesse, 2015; Penna et al., 2018; Herrero et al., 2018; Dixon et al., 2018).

There are still gaps in methodologies to analytically determine the values of these angles (Roy, 1983; Woldenderg and Horsfield, 1983). Here it must be noted that the angle value reflects the minimum energy principle. The application of these methodologies normally requires the data collection in the field, such as slope determination of the waterline and measurements of water and sediment discharge. This collecting activity needs specialized technical teams and adequate equipment, which makes their acquisition very expensive.

Therefore, the objective of the present study was to determine the junction angles: angle of confluence between the channels upstream $(\alpha)$, angle between the main river upstream and downstream main river $(\beta)$, and angle between the tributary and the downstream main river $(\gamma)$, which are shown in Figure 1A, using the law of cosines. The procedure proposed in the present study presents a faster, more accurate, safer and cheaper way to determine the junction angles in fluvial channels, applying the law of cosines in georeferenced aerial images. Then, we used Google Earth Pro and UAV (Unmanned Aerial Vehicle) images, supported in georeferenced points. For the visualization and the comparison of the angles, the Junction Angles Diagram proposed by Kobiyama et al. (2016) (Figure 1B) was adopted.

Rev. Ambient. Água vol. 14 n. 5, e2345 - Taubaté 2019 


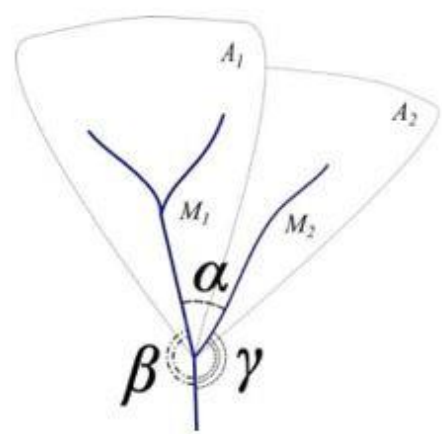

A

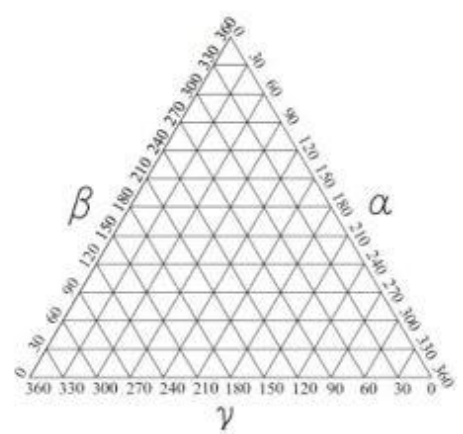

B

Figure 1. Fundamental concept of junction angles: (A) Angles on map; (B) Junction Angles Diagram proposed by Kobiyama et al. (2016).

\section{BASIC THEORY}

\subsection{Confluence on fluvial channels}

At the channel junctions (or confluences) in the drainage network, complex interactions between matter (water and sediment) and energy (channel power) provided by the combination of two different streams are observed (Best, 1987; 1988; Roy, 2008; Santos and Stevaux, 2017). When two channels join, materials (especially water and sediments) change the downstream channel morphology, and sometimes river islands can be temporarily or permanently formed at the main channel confluence site (Benda et al., 2004a). Improving a work of Mosley (1976), Best (1987) proposed a general flow model for confluence zones in open channels, which consists of six different zones (flow stagnation region, flow deflection, flow separation, maximum velocity, flow recovery, and shear layers (Figure 2). The location and extent of these zones respond to variations in both the junction angle and the discharge ratio between the two rivers (tributary and receptor) (Best, 1987; 1988; Biron et al., 1996). This set of zones with distinct characteristics was denominated hydrodynamic zone of confluence by Kenworthy and Rhoads (1995). Benda et al. (2004b) considered the drainage area to define the tributary and the main channel in which the tributary is the one with the smaller area and the main channel is the one with the larger area. Specifically, a tributary junction is defined at a point where two different channels unite, forming a single channel.

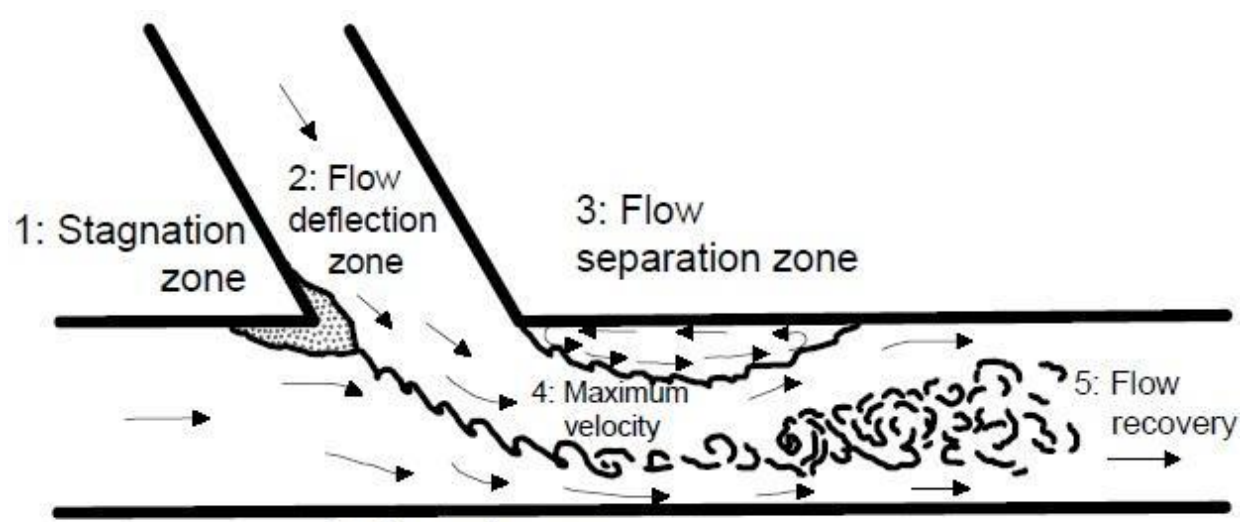

6: Shear layers $n$

Figure 2. Flow dynamics in open confluent channels.

Source: Adapted from Best (1987).

According to Santos and Stevaux (2017), these zones were controlled by the confluence angle and the discharge ratio (Equation 1): 
$Q r=\frac{Q_{t}}{Q_{p}}$

Where $Q_{r}$ is the net discharge ratio $\left[\mathrm{m}^{3} \mathrm{~s}^{-1}\right]$; and $Q_{t}$ and $Q_{p}$ refer to the discharge of the tributary and the main channel, respectively. However, there are other factors that influence, such as symmetry, the momentum ratio (Equation 2).

$$
M r=\frac{\rho t Q t V t}{\rho p Q p V p}
$$

Where $M r$ is the momentum ratio; $\rho$ is the fluid density $\left[\mathrm{g} \mathrm{cm}^{-3}\right]$ and $V$ is the main velocity $\left[\mathrm{m} \mathrm{s}^{-1}\right]$.

Furthermore, symmetry, bed dislocation, transported load (suspended and solid), any differences in density between input streams, and also other local aspects affect junction zones (Biron and Lane, 2008; Riley et al., 2015). In evaluating the 14 studies carried out in the western United States and Canada, Benda et al. (2004b) concluded that the confluences' effects on river morphology are conditioned by the basin shape, by the drainage network patterns and by its density. Other modification factors are local geology because of rock porosity, precipitation intensity, and frequency and magnitude of flood events. The confluence-related hydrogeomorphic forms (e.g., benches, terraces and bars) are dominated by older features at headwaters and by younger characteristics downstream. These forms are derived from flood frequency and magnitude, the sedimentary contribution, and the basin characteristics and size.

\subsection{Determination of the junction angle}

When two channels unite, stemming from them a single downstream channel, the angular relationship of the junction is given by the three-segment gradient, regardless of which are the two angles between the flows (Howard, 1971). The first postulates were that junction angles were controlled by erosion and sediment transport at the confluence (Schumm, 1956) and by the flow gradients of the tributary and the receiving channels (Horton, 1945). Posteriorly, it was evidenced that the angle is directly proportional to the basin order (Lubowe, 1964) and that it varies with the net discharge of the two tributaries (Howard, 1971) and with the discharge per unit width (Mosley, 1976). Discharge, channel width, channel depth, contribution area and slope gradient are important factors for the junction angle formation (Shit and Maiti, 2013). In addition to these factors, junction angles are influenced by variations of land use and occupation in the upstream basin. In order to mathematically determine the junction angle, Horton (1932) assumed that the flow lines follow the channel with a larger slope (Equation 3):

$$
\cos \alpha=\frac{s_{c}}{s_{g}}
$$

Where $S_{c}$ and $S_{g}$ are the slope of the channel and inclination of the hillslope, respectively.

Horton (1945) adapted his model by inferring that the junction angle is a product of the main channel and tributary flow (Equation 4):

$$
\cos \alpha=\frac{s_{0}}{s_{1}}
$$

Where $S_{0}$ and $S_{1}$ denote the gradients of the receiving and the tributary channels, respectively. 
Modifying this model, Howard (1971) determined two input angles $\alpha_{1}$ and $\alpha_{2}$ from the axial extension of the receiving channel on the tributary channel (Equation 5) (Figure 3):

$$
\cos \alpha_{1}=\frac{s_{0}}{s_{1}} ; \quad \cos \alpha_{2}=\frac{s_{0}}{s_{2}}
$$

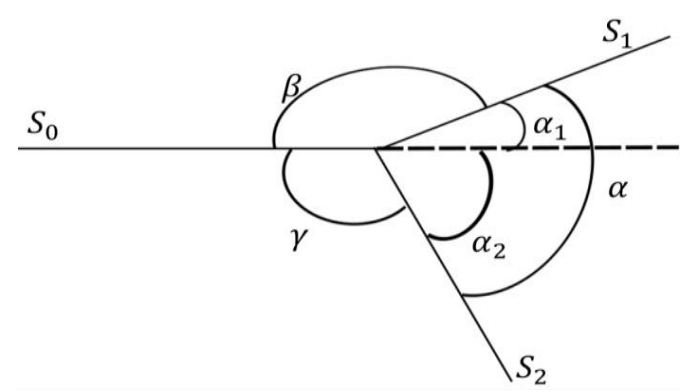

Figure 3. Representation of the junction scheme.

Source: Howard (1971).

Howard (1971) argued that the junction angle in channels can be examined in relation to the working rate (energy) given by gravity and the flow of both inlet and outlet at the junction, and suggested that this connection occurs in a local $(\Omega)$, which can be calculated by summing the costs per unit of length $(\mathrm{Ci})$ in three connections multiplied by the length of the segment ( $\mathrm{Li}$ ) (Equations 6 and 7):

$$
\begin{aligned}
& \Omega=\sum_{i=1}^{3} C_{i} \cdot L_{i} \\
& C_{i} L_{i}=\rho g Q_{i} S_{i}
\end{aligned}
$$

Where $g$ is the gravitational acceleration $\left[\mathrm{m} \mathrm{s}^{2}\right] ; Q_{i}$ is the flow in the channel $\left[\mathrm{m}^{3} \mathrm{~s}^{-1}\right]$; and $S_{i}$ is the channel gradient (energy line slope) $[\mathrm{m} / \mathrm{m}]$.

Hack (1973) proposed that the gradient index of the channel is closely connected to the slope of the channel energy line (Equation 8):

$$
S=K=\frac{d H}{\left(\ln L_{2}-\ln L_{1}\right)}
$$

Where $d H$ is the height difference between the points of interest; and $L$ is the length of the channel between two points.

Roy (1983) and Woldenderg and Horsfield (1983), based on the work of Zamir (1976), affirmed that the junction angle is independent of the channel length $\left(L_{i}\right)$ and emphasized that this is a function of the minimum energy and can be expressed by the law of cosines (Equations $9,10,11,12,13$ and 14):

$$
\begin{aligned}
& \cos \alpha_{1}=\frac{S_{0}^{2}+S_{1}^{2}-S_{2}^{2}}{2 \cdot S_{0} \cdot S_{1}} \\
& \cos \alpha_{2}=\frac{S_{0}^{2}+S_{2}^{2}-S_{1}^{2}}{2 \cdot S_{0} \cdot S_{2}} \\
& \cos \alpha=\frac{S_{0}^{2}-S_{1}^{2}-S_{2}^{2}}{2 \cdot S_{1} \cdot S_{2}}
\end{aligned}
$$

\section{IPABH}




$$
\begin{aligned}
& \alpha=\alpha_{1}+\alpha_{2} \\
& \beta=180-\alpha_{1} \\
& \gamma=180-\alpha_{2}
\end{aligned}
$$

However, Figure 3 demonstrates that the determination of $\beta$ and $\gamma$ is conditioned to have an alignment at an angle of $180^{\circ}$ from $S_{0}$. The fact that it is not very common to have fluvial channels with the $\mathrm{Y}$ type format at a natural junction proves the limitation of this methodology.

\section{MATERIALS AND METHODS}

\subsection{Study Area}

The Sinos River Basin is located in the northeast of Rio Grande do Sul state, Brazil, between the geographic coordinates $29^{\circ} 20^{\prime}$ and $30^{\circ} 10^{\prime} \mathrm{S}$, and $50^{\circ} 15^{\prime}$ and $51^{\circ} 20^{\prime} \mathrm{W}$ (Figure 4). The basin has an area of $3,746.68 \mathrm{~km}^{2}$ and a total population estimated at 1,249,100 inhabitants. The drainage network of the basin is composed of the Sinos River, Rolante River, Ilha River and Paranhana River. The latter has its sources in the cities of Gramado and Canela, at an altitude of approximately $900 \mathrm{~m}$, and its outlet is located between the cities of Parobé and Taquara.

The Paranhana River basin approximately has an area of $574 \mathrm{~km}^{2}$ and an extension of $50 \mathrm{~km}$ in its main channel, with several cascades. The Sinos River has its headwaters in Caraá municipality, at an altitude of approximately $800 \mathrm{~m}$, and its outlet is located at the border between the municipalities of Canoas and São Leopoldo, at an altitude of approximately $4 \mathrm{~m}$. This river has an approximate extension of $190 \mathrm{~km}$, covering 13 municipalities. The upper part of the Sinos River, which is determined from the junction point that the present study selected, has a drainage area of $1,791 \mathrm{~km}^{2}$.

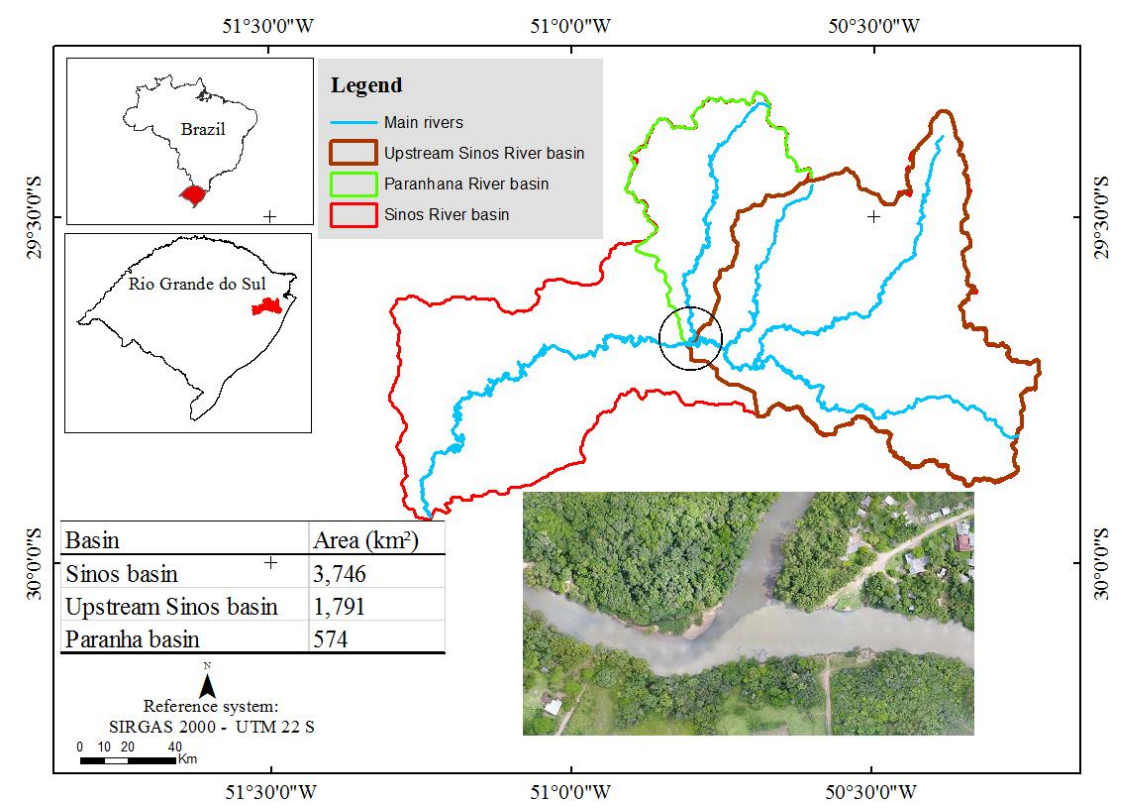

Figure 4. Location of the confluence point between the Sinos River and the Paranhana River.

\subsection{Obtaining aerial images}

Google Earth Pro images is formed from a mixture of images from sensors of diverse resolutions, arranged to form a continuous image of the whole terrestrial globe. A detailed 
description of the procedures for obtaining and making these images available can be found in Lopes (2009). The image used to perform the present study came from a flight conducted on August $20^{\text {th }}, 2017$. The image determined from the UAV was made on November $16^{\text {th }}, 2017$. For the acquisition of this image, the present study used a multi-rotor UAV of four propellers, Model Phantum 4, with a digital camera Model FC6310, with a resolution of 5472 x 3648 pixels, focal length of $8.8 \mathrm{~mm}$, pixel of $2.41 \times 2.41 \mathrm{~cm}$ and a Memory Stick storage card with a capacity of $1024 \mathrm{Mb}$. Table 1 shows a summary of flight specifications and conditions. Figure 5A schematically shows the flight plan. The errors in altitude (Z) are represented by the color of the ellipse and the errors in east orientation (X) and north orientation (Y) are represented by the shape of the ellipse (Figure 5B). The main error was $46.35 \mathrm{~cm}$, $24.37 \mathrm{~cm}$ and $68.55 \mathrm{~cm}$, in the $\mathrm{X}, \mathrm{Y}$ and $\mathrm{Z}$ directions, respectively.

Table 1. Parameters of the flight mission.

\begin{tabular}{lccccccc}
\hline $\begin{array}{l}\text { Number } \\
\text { photos }\end{array}$ & $\begin{array}{c}\text { Covered } \\
\text { area }\end{array}$ & $\begin{array}{c}\text { Weather } \\
\text { conditions }\end{array}$ & $\begin{array}{c}\text { Flight } \\
\text { speed }\end{array}$ & $\begin{array}{c}\text { Estimated flight } \\
\text { time }\end{array}$ & $\begin{array}{c}\text { Flight } \\
\text { altitude }\end{array}$ & $\begin{array}{c}\text { Time between } \\
\text { two photos }\end{array}$ & Overlap \\
\hline 258 & $0.236 \mathrm{~km}^{2}$ & Partly cloudy & $8 \mathrm{~m} \mathrm{~s}^{-1}$ & 6 min and $41 \mathrm{sec}$. & $108 \mathrm{~m}$ & $0.2 \mathrm{sec}$. & $80 \%$ \\
\hline
\end{tabular}

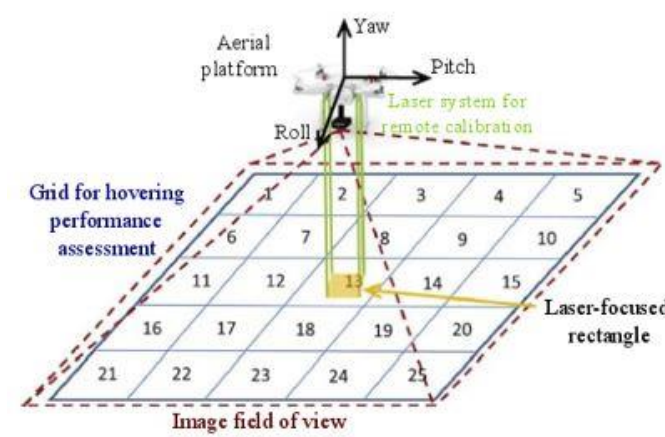

A

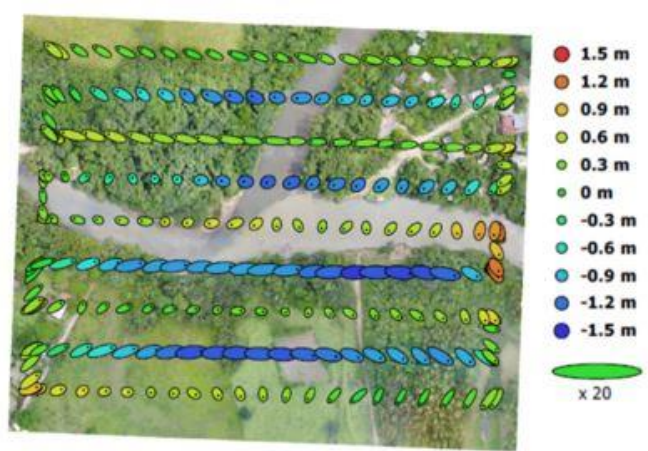

B

Figure 5. (A) Scheme of the flight plan; (B) possible errors in $\mathrm{X}, \mathrm{Y}$ and $\mathrm{Z}$ axes. Source: Adapted from Taurus (2016).

\subsection{Georeferencing of images}

For the determination of the coordinates in the field, a reference frame was implanted, where the equipment base was installed. Subsequently spatial targets were distributed at strategic points (points of support) in order to georeference the images. The coordinates of the base were determined by post-processing of the base, that is, precise point positioning (PPP). This system is free and available online for the GNSS (Global Navigation Satellite System) data processing, which makes use of the GPS Precise Point Positioning (GPS) program developed by the Geodetic Survey Division of Natural Resources of Canada (NRCan). It allows users with GPS and/or GLONASS receivers to obtain precision coordinates in the Geocentric Reference System for the Americas (SIRGAS2000) and the International Terrestrial Reference Frame (ITRF) (IBGE, 2017). After determining the correct coordinate of the base, based on the PPP, the coordinates of the strategic points were translated. For this procedure, the software GNSS solutions was used. The field survey for georeferencing as well as the flight with the UAV was carried out on November $16^{\text {th }}, 2017$ from $4 \mathrm{~h} 20 \mathrm{pm}$ to $5 \mathrm{~h} 30 \mathrm{pm}$. The coordinate of the base UTM (m) MC -51: 6,716,0149.363 $\mathrm{m}(\mathrm{N})$ and 518,400.842 $\mathrm{m}(\mathrm{E})$, obtained by the static mode and orbits of fast satellites.

\subsection{Determination of the junction point $(p)$}

Woldenberg and Horsfield (1983) commented that the problem of the three points, point of junction, has been debated over 200 years, being approached predominantly in three ways. 
First, the found junction-point is at a lower cost location that is identical to the equilibrium point of the forces. In the second, at the lowest point to the point of equilibrium. And the third at a point that minimizes the sum of the costs of the channels by an interactive process of moving the junction point to the minimum point. These authors presented an analytical solution for the determination of the point $(p)$; however this solution is an alignment at an angle of $180^{\circ}$ from $\mathrm{S}_{0}$ (Figure 3). Since the dispersion of the channels mostly did not follow this standard, the present study determined the point $(p)$ taking into account the alignments of the receiving and affluent channel margins (Figure 6A).

For this, an extension (red line) of the right-margin alignment of the tributary channel was made, upstream to downstream. Subsequently, an alignment of the right margin of the receiving channel was made, from downstream to upstream, until the alignment previously made, thus defining point ( $p$ ) (Figure 6B). It should be noted that the determination of $(p)$, is due to the researcher's perception to define the alignment that best represents the alignment of the channels. Moreover, the dynamics and mobility of the channels (Leopold and Maddock Jr., $1953)$, the point $(p)$ varies according to the conditions in the channels. In this sense, its determination will represent the current conditions of field collections. From point $(p)$, the segment of interest was aligned for the definition of the coordinates $\left(X_{0}, Y_{0} ; X_{1}, Y_{1} ;\right.$ and $\left.X_{2}, Y_{2}\right)$, (Figure 6C). This alignment occurred from point $(p)$ to the middle of the channel of the given location. The definition of the length of this section was 4 times larger than the channel width, near point $(p)$. Figure $6 \mathrm{C}$ represents the alignments in the image obtained with the UAV, and Figure 6D represents the alignments defined in the Google Earth Pro image.

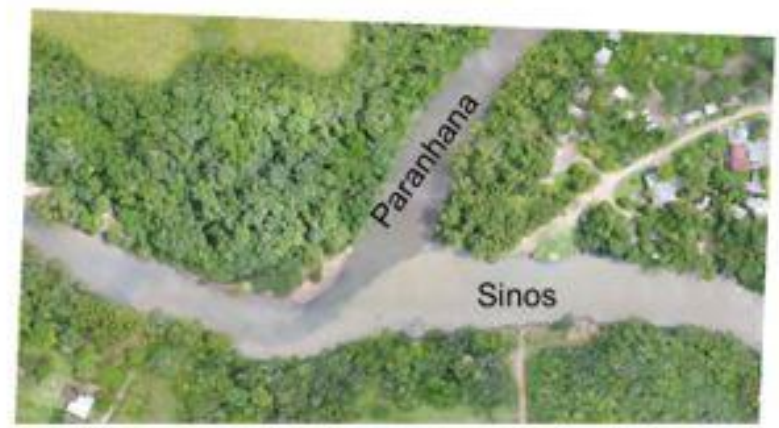

A

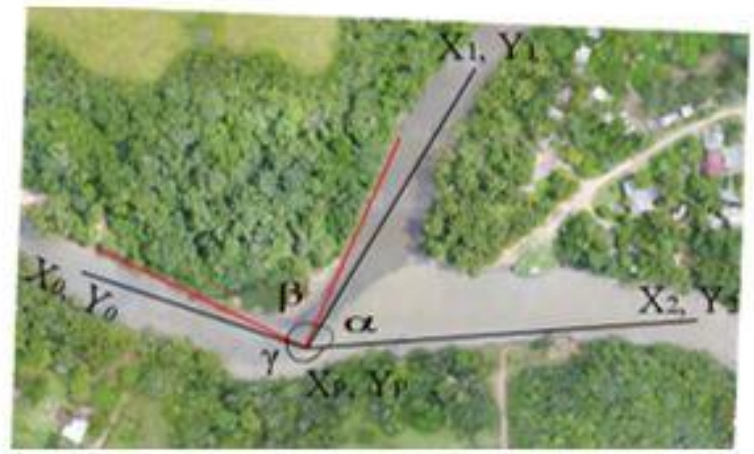

C

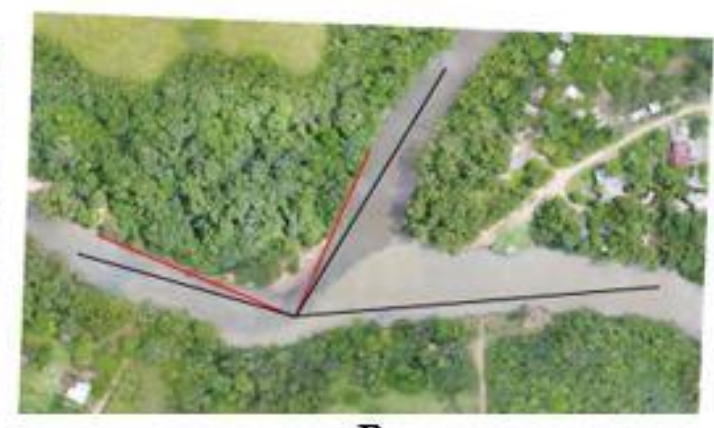

B

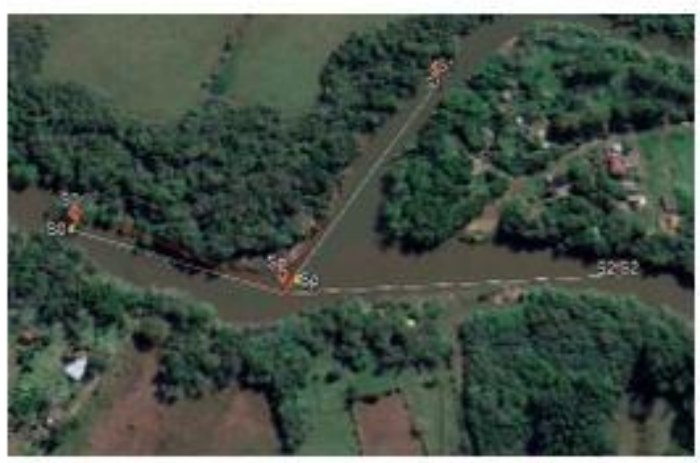

D

Figure 6. Representative scheme for determining the intersection point of the channels and the channel gradient of the study area: (A) visualization at the junction of the channels; (B) definition of the alignment for the determined point $p$; (C) definition of the length of the study area from images collected UAV and (D) definition of the length of the study area from Google Earth Pro images. 


\subsection{Determination of junction angles from georeferenced data}

Based on the assumptions presented by Zamir (1976), Roy (1983), and Woldenderg and Horsfield (1983), the present study determined the angles $\alpha, \beta$ and $\gamma$ (Figure 7) by using georeferenced aerial images collected with UAV and DGPS (Differential Global Positioning Systems). Determination of the respective angles are expressed as (Equations 15, 16 and 17):

$$
\begin{aligned}
& \alpha=\cos ^{-1} \frac{\left(b^{2}+c^{2}-a^{2}\right)}{(2 * b * c)} \\
& \beta=\cos ^{-1} \frac{\left(a^{2}+c^{2}-b^{2}\right)}{(2 * a * c)} \\
& \gamma=\cos ^{-1} \frac{\left(a^{2}+b^{2}-c^{2}\right)}{(2 * a * b)}
\end{aligned}
$$

The horizontal distance between the points $S_{0}, S 1$ and $S_{2}$ are determined from the Euclidean distance (Equation 18):

$$
D(m)=\sqrt{\left(X_{n+1}-X_{n}\right)^{2}+\left(Y_{n+1}-Y_{n}\right)^{2}+\left(Z_{n+1}-Z_{n}\right)^{2}}
$$

Where $D$ is the distance between the $\left(\underline{S}_{0} \underline{S}_{1}, \underline{S}_{1} \underline{S}_{2}, \underline{S}_{0} \underline{S}_{2}\right)$.

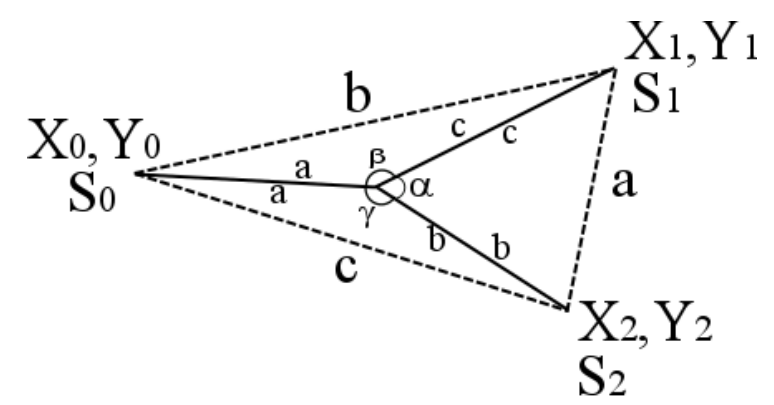

Figure 7. Determination scheme of the junction angle based on georeferenced data.

\section{RESULTS AND DISCUSSION}

Adopting Equations (9) to (14), and based on the minimum energy, the values of the angles $\alpha, \beta$ and $\gamma$ were determined (Table 2). To determine the height difference between the points (S0, S1 and S2) used in determining the channel energy line (Equation 8), DGPS-RTK equipment was used. The used flow data were from the discharge stations Foz do Paranhana (87376000) and Taquara Montante (87374000), which are located upstream and downstream of the confluence point, respectively. These data were obtained from the Hydrological Information System (HidroWeb) on the ANA (National Water Agency) website. This electronic system freely provides the database of information collected by the National Hydrometeorological Network (RHN).

Table 2. Values found as a function of the minimum energy.

\begin{tabular}{lccc}
\hline Basin & Slope $(\mathrm{S})(\mathrm{m} / \mathrm{m})$ & Angle & (minimum energy) \\
\hline Sinos downstream (S0) & 0.0023 & $\alpha$ & $154^{\circ} 23^{\prime} 13^{\prime \prime}$ \\
Paranhana (S1) & 0.0051 & $\beta$ & $97^{\circ} 45^{\prime} 46^{\prime \prime}$ \\
Sinos upstream (S2) & 0.0053 & $\gamma$ & $107^{\circ} 51^{\prime} 01^{\prime \prime}$ \\
\hline
\end{tabular}


For determining the junction angles in fluvial channels by applying the law of cosines in georeferenced aerial images, Table 3 shows the values referring to the aerial images collected with the UAV and the values from the Google Earth Pro image.

Table 3. Values of junction angles obtained: (a) with the georeferenced image from UAV, and (b) from Google Earth Pro image.

\begin{tabular}{|c|c|c|c|c|c|c|c|}
\hline \multicolumn{8}{|c|}{ (a) } \\
\hline Point & $\begin{array}{l}\text { Coordinate } \mathrm{E} \\
(\mathrm{m})\end{array}$ & $\begin{array}{l}\text { Coordinate } \mathrm{N} \\
(\mathrm{m})\end{array}$ & Angle & From UAV & $a(\mathrm{~m})$ & $b(\mathrm{~m})$ & $c(\mathrm{~m})$ \\
\hline SP & $518,281.014$ & $6,716,006.668$ & $\alpha$ & $57^{\circ} 55^{\prime} 14^{\prime \prime}$ & 219.008 & 237.658 & 212.326 \\
\hline So & $518,110.357$ & $6,716,049.113$ & $\beta$ & $106^{\circ} 36^{\prime} 57^{\prime \prime}$ & 175.856 & 312.029 & 212.326 \\
\hline $\mathrm{S} 1$ & $518,389.042$ & $6,716,189.459$ & $\gamma$ & $195^{\circ} 27^{\prime} 49^{\prime \prime}$ & 175.856 & 237.658 & 409.839 \\
\hline $\mathrm{S} 2$ & $518,518.591$ & $6,716,012.875$ & & & & & \\
\hline \multicolumn{8}{|c|}{ (b) } \\
\hline Point & $\begin{array}{l}\text { Coordinate } \mathrm{E} \\
(\mathrm{m})\end{array}$ & $\begin{array}{l}\text { Coordinate } \mathrm{N} \\
(\mathrm{m})\end{array}$ & Angle & $\begin{array}{c}\text { From Google Earth } \\
\text { Pro }\end{array}$ & $a(\mathrm{~m})$ & $b(\mathrm{~m})$ & $c(\mathrm{~m})$ \\
\hline SP & $518,272.47$ & $6,716,001.190$ & $\alpha$ & $54^{\circ} 14^{\prime} 46^{\prime \prime}$ & 213.663 & 246.398 & 219.256 \\
\hline So & $518,114.00$ & $6,716,053.000$ & $\beta$ & $104^{\circ} 55^{\prime} 52^{\prime \prime}$ & 166.724 & 307.746 & 219.256 \\
\hline $\mathrm{S} 1$ & $518,392.00$ & $6,716,185.000$ & $\gamma$ & $200^{\circ} 49^{\prime} 22^{\prime \prime}$ & 166.724 & 246.398 & 406.575 \\
\hline $\mathrm{S} 2$ & $518,518.59$ & $6,716,012.875$ & & & & & \\
\hline
\end{tabular}

Comparing the calculated values from the minimum energy with the values measured from Google Earth PRO and UAV images, the difference values of $\alpha$ are $100^{\circ} 08^{\prime 2} 27^{\prime \prime}$ and $96^{\circ} 27^{\prime} 59^{\prime \prime}$, respectively. When comparing the Google Earth Pro and UAV images, the difference of $\alpha$ is $2^{\circ} 19^{\prime} 32$. For $\beta$, the differences between the methodology of the minimum energy and from Google Earth PRO and UAV images are $7^{\circ} 10^{\prime} 6^{\prime \prime}$ and $8^{\circ} 51^{\prime} 11^{\prime \prime}$, respectively. When comparing Google Earth Pro and UAV images, the difference of $\beta$ is $1^{\circ} 1^{\prime} 5 "$ ". For $\gamma$, the difference between the minimum energy methodology and from Google Earth PRO and UAV images are

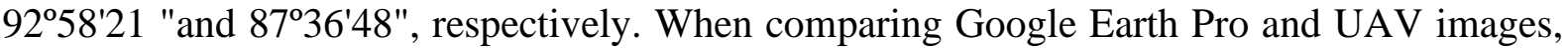
the difference of $\gamma$ is $5^{\circ} 21^{\prime} 33^{\prime \prime}$.

This evaluation of the values obtained as a function of the minimum energy confirms that this methodology was not suitable to the study area. This assertion is supported by Figure 3 where the determination of $\alpha, \beta$ and $\gamma$ was conditioned to an alignment of $180^{\circ}$ from $S_{0}$. It did not match with the channels of the present study. In addition, the occurrence of the "Y" shaped junctions in fluvial channels is not very common.

Limitation of the method based on the minimum energy also results from the difficulty to determine the slope between the points of interest. In the case of river banks, the slope determination of the water line by topographic survey becomes very laborious. And when the GNSS system is adopted, there is a limitation of satellite signal interference due to the riparian vegetation.

As observed in Table 3, there is a difference, for each point, between the coordinates obtained from the Google Earth Pro and with UAV images. Here it must be noted that the coordinates obtained by the UAV flight and georeferenced in the field with the DGPS-RTK are more accurate than the ones from Google Earth Pro image. Thus, it may be said that the values obtained with the UAV flight better represent the angles $\alpha, \beta$ and $\gamma$. The technique's limitations (disadvantages) include the need to perform the precision georeferencing concomitant to the flight with UAV as well as the need to know how to use the described equipment.

On the other hand, the satellite image has the advantage of being more easily obtained for the citizen user. Furthermore, it provides the advantage of applying the methodology, cosine 
law in georeferenced aerial images, in a wider range of places.

In order to better visualize and compare the obtained angles, the $\alpha, \beta$ and $\gamma$ values of the georeferenced aerial images with the minimum-energy values were plotted in the Junction Angles Diagram (adapted from Kobiyama et al., 2016) (Figure 8). The plotted points in the diagram demonstrate a good coherence between the values obtained from the georeferenced image and a discrepancy with the values obtained from the minimum energy.

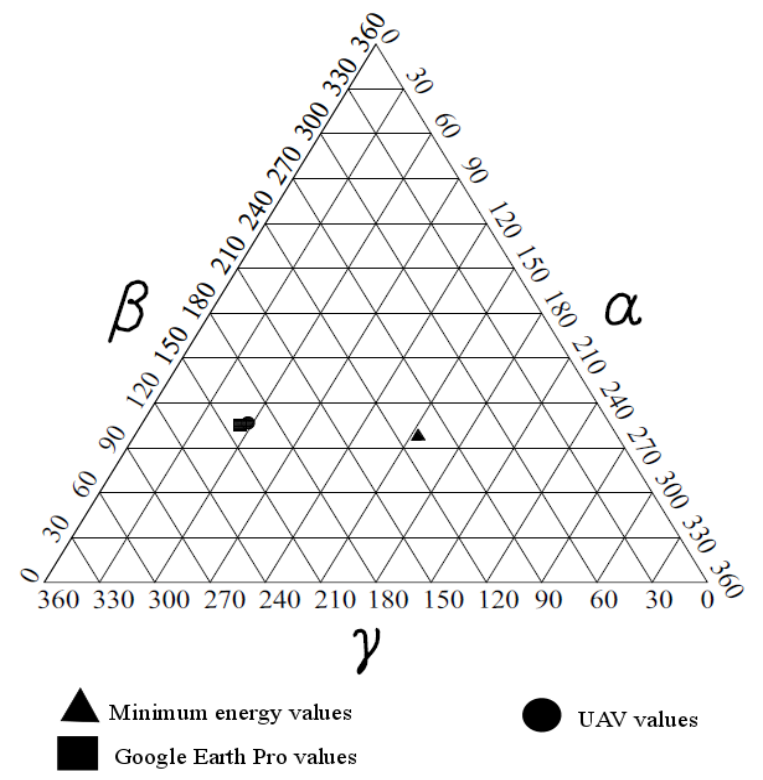

Figure 8. Junction Angles Diagram with the obtained values of $\alpha, \beta$ and $\gamma$.

The comparison between the two methods (georeferenced images and minimum energy) allows us to observe that the use of the first one is easier to obtain the values of the junction angles, because it does not require to measure flow and the energy line slope. Thus, this method is cheaper, faster, safer and more accurate. Another vantage of this method is its mathematical simplicity, just using the law of cosines. Furthermore, it may possibly be applied in aerial images obtained from high-resolution satellites. Then the evaluation of the dynamics of the junction angles can be possible using previous images. Thus, the present study is one example of the efficiency of the georeferenced-images method.

\section{CONCLUSION}

Aiming to contribute to a better understanding of the fluvial and geomorphological processes occurring in a river basin, the present study had the objective of determining the junction angles in fluvial channels, applying the law of cosines in georeferenced aerial images from Google Earth Pro images and collected with UAV. For better visualization and comparison between the obtained values of the angles $\alpha, \beta$ and $\gamma$, they were plotted on the Junction Angles Diagram (adapted from Kobiyama et al., 2016).

In this sense, the importance of the insertion of new technologies in environmental studies is highlighted. The use of aerial images, collected with UAV, provides a detailed view on small scales, thus providing a better understanding of the complexity and integration of the involved processes. In addition, the use of the UAV has the advantage of acquiring data in a faster and more practical way, even enabling studies in places of difficult access. The high accuracy provided by georeferencing contributes significantly to the environmental studies, because the measured data certainly has better accuracy, and consequently provides a better understanding of the measured variables.

\section{IPABH}

Rev. Ambient. Água vol. 14 n. 5, e2345 - Taubaté 2019 
The use of aerial imagery obtained by satellite, Google Earth Pro image, has the great advantage of its ease of access and the high degree of applicability in various parts of the Earth. Furthermore, evaluation of the dynamics of the junction angles can be possible in past times, which allows the understanding of hydrodynamic and morphodynamic processes in basins

It was verified that the values determined from georeferenced images presented values more coherent with the field reality, than the values obtained from minimum energy. It confirms the efficiency of the proposed methodology. The use of the Law of Cosines, using georeferenced aerial images, was shown to be simple and efficient for the study to determine the angles $\alpha, \beta$ and $\gamma$ in fluvial channels. In this sense, the proposed methodology presents great potential for its applicability. Its further applicability should be tested in various cases in Brazil and other countries.

\section{REFERENCES}

ALOMARI, N. K.; YUSUF, B.; MOHAMMAD, T. A.; GHAZALI, A. H. Experimental investigation of scour at a channel junctions of different diversion angles and bed width ratios. Catena, v. 166, p. 10-20, 2018. https://doi.org/10.1016/j.catena.2018.03.013

BENDA, L.; POFF, L.; MILLER, D.; DUNNE, T.; REEVES, G.; PESS, G.; POLLOCK, M. The Network Dynamics Hypothesis: How Channel Networks Structure Riverine Habitats. BioScience, v. 54, n. 5, p. 413-427, 2004a. https://doi.org/10.1641/00063568(2004)054[0413:TNDHHC]2.0.CO;2

BENDA, L.; ANDRAS, K.; MILLER, D.; BIGELOW, P. Confluence effects in rivers: Interactions of basin scale, network geometry, and disturbance regimes. Water Resources Research, v. 40, 2004b. https://doi.org/10.1029/2003WR002583

BEST, J. L. Flow dynamics at river channel confluences: Implications for sediment transport and bed morphology. In: ETHERIDGE, F. G.; FLORES, R. M.; HARVEY, M. D. (eds.). Recent Developments in Fluvial Sedimentology. [S.1.]: SEPM, 1987. p. 27-35. https://doi.org/10.2110/pec.87.39

BEST, J. L. Sediment transport and bed morphology at river channel confluences. Sedimentology, v. 35, p. 481-498, 1988. https://doi.org/10.1111/j.1365-3091.1988.tb 00999.x

BEST, J. L.; RHOADS, B. L. Sediment transport, bed morphology and the sedimentology of river channel confluences. In: RICE, S.; ROY, A.; RHOADS, B. (eds.). River Confluences, Tributaries and the Fluvial Network. New York: John Wiley \& Sons, 2008. p. 45-72.

BEVEN, K, J.; WOOD, E. F.; SIVAPALAN, M. On hydrological heterogeneity - catchment morphology and catchment response. Journal of Hydrology, v. 100, p. 353-375, 1988. https://doi.org/ 10.1016/0022-1694(88)90192-8

BIRON, P.; BEST, J. L.; ROY, A. Effects of bed discordance on flow dynamics at open channel confluences. Journal of Hydraulic Engineering, v. 122, n. 12, p. 676-682, 1996. https://doi.org/10.1061/(ASCE)0733-9429(1996)122:12(676)

BIRON, P. M.; LANE, S. N. Modelling hydraulics and sediment transport at river confluences. In: RICE, S. P.; ROY, A. G.; RHOADS, B. L. (eds.). River confluences, tributaries and the fluvial network. New York: John Wiley \& Sons, 2008. p. 17-43. https://doi.org/10.1002/9780470760383.ch3 
DIXON, S. J.; SAMBROOK, S. G. H.; BEST, J. L.; NICHOLAS, A. P.; BULL, J. M.; VARDY, M. E.; SARKER, M. H.; GOODBRED, S. The planform mobility of river channel confluences: Insights from analysis of remotely sensed imagery. Earth-Science Reviews, v. 176, p. 1-18, 2018. http://dx.doi.org/10.1016/j.earscirev.2017.09.009

HACK, J. T. Stream profile analysis and stream gradient index. Journal of Resources $\begin{array}{lllllll}\text { Geological Survey, } & \text { v. } 1, \quad \text { n. } 4, & \text { p. }\end{array}$ https://pubs.usgs.gov/journal/1973/vol1issue4/report.pdf

HERRERO, H. S.; LOZADA, J. M. D.; GARCÍA, C. M.; SZUPIANY, R. N.; BEST, J.; PAGOT, M. The influence of tributary flow density differences on the hydrodynamic behavior of a confluent meander bend and implications for flow mixing. $\begin{array}{llllll}\text { Geomorphology, } & \text { v. } & 304, & \text { p. } & 99-112, & \end{array}$ https://doi.org/10.1016/j.geomorph.2017.12.025

HOOSHYAR, M.; SINGH, A.; WANG, D. Hydrologic controls on junction angle of river network, Water Resources Research, v. 53, p. 4073-4083, 2017. https://doi.org/10.1002/2016WR020267

HORTON, R. E. Drainage Basin Characteristics. Transactions of the American Geophysical Union, v. 13, p. 350-361, 1932. https://doi.org/10.1029/TR013i001p00350

HORTON, R. E. Erosional development of stream and their drainage basins, hydrophysical approach to quantitative morphology. Bulletin of the Geological Society of America, v. 56, p. 275-370, $1945 . \quad$ https://doi.org/10.1130/00167606(1945)56[275:EDOSAT]2.0.CO;2

HOWARD, A. D. Optimal angles of stream junction: Geometric, stability to capture and minimum power criteria. Water Resources Research, v. 7, n. 4, p. 863-873, 1971. https://doi.org/10.1029/WR007i004p00863

IBGE. Manual do Usuário Aplicativo Online IBGE-PPP. Rio de Janeiro, 2017. 46 p.

KENWORTHY, S. T.; RHOADS, B. L. Hydrologic control of spatial patterns of suspended sediment concentration at a small stream confluence. Journal of Hydrology, v. 168, p. 251-63, 1995. https://doi.org/10.1016/0022-1694(94)02644-Q

KOBIYAMA, M.; GODOY, J. V. Z.; PEREIRA, M. A. F.; MICHEL, G. P.; MELO, C. M. Análise do ângulo de junção com consideração da hierarquização fluvial de Strahler e Shreve. In: SIMPÓSIO NACIONAL DE GEOMORFOLOGIA, 11., 2016, Maringá. Anais[...] Maringá: EGB, 2016. 8p.

LEOPOLD, L. B.; MADDOCK JR., T. The hydraulic geometry of stream channels and some physiographic implications. Washington: USGS, 1953. 56p.

LOPES, E. E. Proposta metodológica para validação de imagens de alta resolução do Google Earth para a produção de mapas. 2009. 112f. Dissertação (Mestrado em Engenharia Civil) - Universidade Federal de Santa Catarina, Florianópolis, 2009.

LUBOWE, J. K. Stream junction angles in the dendritic drainage pattern. American Journal Science, v. 262, p. 325-339, 1964. https://doi.org/10.2475/ajs.262.3.325

MOSLEY, M. P. An experimental study of channel confluences. Journal of Geology, v. 84, p. 535-562, 1976. https://doi.org/10.1086/628230 
PARK, E.; LATRUBESSE, E. M. Surface water types and sediment distribution patterns at the confluence of mega rivers: The Solimões-Amazon and Negro Rivers junction. Water Resources Research, v. 51, p. 6197-6213, 2015. doi:10.1002/2014WR016757

PENNA, N.; DE MARCHIS, M.; CANELAS, O. B.; NAPOLI, E.; CARDOSO, A. H.; GAUDIO, R. Effect of the Junction Angle on Turbulent Flow at a Hydraulic Confluence. Water, v. 10, n. 4, 2018. https://doi.org/10.3390/w10040469

RILEY, J. D.; RHOADS, B. L.; PARSONS, D. R.; JOHNSON, K. K. Influence of junction angle on three-dimensional flow structure and bed morphology at confluente meander bends during different hydrological conditions. Earth Surface Processes and Landforms, v. 40, p. 252-271, 2015. https://doi.org/10.1002/esp.3624

ROY, A. G. Optimal Angular Geometry Models of River Branching. Geographical Analysis, v. 15, n. 2, p.87-96, 1983.

ROY, A. G. River Channel Confluences. In: RICE, S. P.; ROY, A. G.; RHOADS, B. L. (eds.). River confluences, tributaries and the fluvial network. New York: John Wiley \& Sons, 2008. p. 13-16 https://doi.org/10.1111/j.1538-4632.1983.tb00771.x

SANTOS, V. C. dos; STEVAUX, J. C. Processos fluviais e morfologia em confluências de canais: uma revisão. Revista Brasileira de Geomorfologia, v. 18, n. 1, 15 p., 2017. http://dx.doi.org/10.20502/rbg.v18i1.1042

SHIT, P. K.; MAITI, R. Confluence Dynamics in an Ephemeral Gully Basin (A Case Study at Rangamati, Paschim Medinipur, West Bengal, India). Research Journal of Applied Sciences, Engineering and Technology, v. 15, n. 5, p. 3895-3911, 2013.

SCHUMM, S. A. Evolution of drainage systems and slopes in badlands at Perth Amboy, New Jersey. Geological American Bulletin, v. 67, n. 67, p. 597-646, 1956. https://doi.org/10.1130/0016-7606(1956)67[597:EODSAS]2.0.CO;2

SMALL, R. J. The study of landforms. $2^{\text {nd }}$ ed. Cambridge: Cambridge University Press, 1978. $502 \mathrm{p}$.

WOLDENBERG, M. J.; HORSFIELD, K. Finding the Optimal Lengths for Three Branches at a Junction. Journal theoretical Biology, v. 104, p. 301-318, 1983. https://doi.org/10.1016/0022-5193(83)90417-4

YUKAWA, S.; WATANABE, T.; HARA, K. Bifurcation Angle Distribution in the Japanese River Network. Journal of the Physical Society of Japan, v. 88, 2019. https://doi.org/10.7566/JPSJ.88.024901

ZAMIR, M. Optimality Principles in Arterial Branching. Journal of Theoretical Biology, n. 62, p. 227-251, 1976. https://doi.org/10.1016/0022-5193(76)90058-8 